\title{
Bolting and Flowering Response of Lactuca georgica, a Wild Lettuce Relative, to Low Temperatures
}

\author{
Alex Beharav ${ }^{1 * \#, ~ B a r b a r a ~ H e l l i e r ~}{ }^{2 *}$ \\ ${ }^{1}$ Institute of Evolution, University of Haifa, Mt. Carmel, Haifa, Israel \\ ${ }^{2}$ USDA-ARS, Plant Germplasm Introduction and Testing Research Unit, Washington State University, Pullman, WA, USA \\ Email: "abeharav@univ.haifa.ac.il
}

How to cite this paper: Beharav, A. and Hellier, B. (2020) Bolting and Flowering Response of Lactuca georgica, a Wild Lettuce Relative, to Low Temperatures. American Journal of Plant Sciences, 11, 2139-2154. https://doi.org/10.4236/ajps.2020.1112150

Received: November 7, 2020

Accepted: December 28, 2020

Published: December 31, 2020

Copyright () 2020 by author(s) and Scientific Research Publishing Inc. This work is licensed under the Creative Commons Attribution International License (CC BY 4.0).

http://creativecommons.org/licenses/by/4.0/

\section{(c) (i) Open Access}

\begin{abstract}
To learn about the phenological adaptation of Lactuca georgica Grossh., a wild relative of domesticated lettuce, we studied seed sampled accessions obtained from individual plants at 19 locations throughout six regions in Armenia, and from two natural populations in Dagestan (Russian Federation) collected as bulk samples. The effects of various vernalization treatments on time to bolting, flowering and seed production time were investigated during four successive years at different growth stages of $L$. georgica plants. We demonstrate that low temperatures play a major role in stimulating the reproduction process of $L$. georgica plants. Our results would suggest that for $L$. georgica: 1) There is an obligatory (or nearly so) vernalization requirement; 2) Plant age, vernalization duration, and genotype of original sample have a role in bolting and flowering regulation; 3) Some plants behaved as typical annuals, responding to vernalization treatment at the seedling stage, but, most did not; 4) Four months of vernalization could be adequate to reach bolting in plants with a developed vegetative rosette, for most-but not all-samples; 5) In order to find the best solution for stimulating the reproductive process of multiple genotypes, it seems that further study should focus on about $4-6$ months of vernalization at $4^{\circ} \mathrm{C}$ applied to plants of about $10-22$ months old vegetative rosettes, with controlled post-vernalization condition; 6) L. georgica germplasm could be used as a source for delayed bolting in breeding of domesticated lettuce varieties.
\end{abstract}

\section{Keywords}

Gene Pools, Lactuca sativa, Phenological Adaptation, Plant Age, Vernalization Duration, Wild Lettuce 


\section{Introduction}

The genus Lactuca L. [Compositae (Asteraceae), tribe Cichorieae, subclade Lactucinae [1] is comprised of 100 [1] to 148 species [2], which are mainly distributed in the Northern Hemisphere ([3], and literature cited therein). The domesticated species in the genus, Lactuca sativa L. (lettuce), is one of the most important and widely distributed leafy vegetables around the world. Domestication has resulted in limited genetic variation in the crop making it vulnerable to diseases, pests, and environmental stresses.

In recent years, we have performed extensive studies on the characterization of wild Lactuca spp. originating from Southwest Asia, the center of diversity for wild species closely related to domesticated lettuce (Wild Lactuca Relatives, WLRs) [4]. Unique new collections of L. serriola, L. aculeata Boiss., L. georgica Grossh., and L. altaica Fisch. \& C. A. Mey. (four of the seven wild species, according to previous literature [4] [5], in the primary lettuce gene pool, LGP-1), and $L$. saligna (in LPG-2) from Israel and Armenia were studied, as well as a few samples previously collected from Jordan, Turkey and other Mediterranean and European countries. The objectives of our research are related to the identification, collection, characterization, conservation, and sustainable use of these rich genetic sources for lettuce improvement. These studies included eco-geographical distribution [6] [7] [8], genetic, morphological and phenological diversity [9] [10] [11] [12] [13], downy mildew resistance [10] [14] [15] [16] [17] and variation of biologically active sesquiterpene lactone contents [18] [19] [20] [21]. Obtained results strongly support the use of these species specifically and WLRs in general as rich genetic sources for lettuce improvement.

One of the aforementioned species, L. georgica, is a diploid $(2 n=2 x=18)$ [4] [22], $50-300 \mathrm{~cm}$ tall, biennial plant according to Gabrielian and Fragman-Sapir ([23], p. 80). Blooming in nature occurs in July-August [23]. L. georgica's distribution is restricted to the Euxinian-Hyrcanian region of southwest Asia (Caucasia, Northeast Anatolia, and North Iran) ([4], and literature cited therein) and in the past, was observed at altitudes ranging from 1500 to $2300 \mathrm{~m}$ above sea level [23].

Prior to 2009, in world gene bank collections of wild Lactuca spp., L. georgica was represented by only a single sample [24] [25], "LAC 327". Consequently, $L$. georgica was not studied by lettuce breeders and crop evolutionists [3]. Thus, we strove to increase the number of available $L$. georgica samples for comparative genetic and physiological studies.

Plants originating from a seed sample of the L. georgica "LAC 327" were grown in 2009 and morphologically characterized alongside of wild Lactuca spp. samples representing (according to Lebeda et al. [5]) the LGP-1 ( $L$. aculeata, $L$. serriola, $L$. dregeana, and $L$. altaica), LGP-2 (L. saligna), and the section Mulgedium (Lactuca tatarica (L.) C. A. Mey.). Field regeneration was conducted at the Institute of Evolution (IOE), Haifa University (HU), Israel and followed all standard seed multiplication protocols, except that seeds were not vernalized. All plants of the $L$. georgica sample did not bolt, even after all plants from the other 
species bolted, flowered, and had ripe seeds (data not published). Thus, we hypothesize that plants of $L$. georgica require a cold season for bolting and floral initiation.

Bolting resistance is an important breeding aim of vegetative crops [26]. Therefore, information on the phenology of $L$. georgica, and, in particular, on the environmentally mediated response, is of great importance. It is also important to learn if all L. georgica germplasm is indeed biennial, which is a commonly-accepted "fact" that has been cited for over one hundred years in the literature ([23], p. 80), but without any experimental data to supported it. A biennial plant, by definition, completes its life-cycle during two years: in the first year, plants generally make only leaves and other vegetative structures, while in the second year they flower, produce seed and die. The change from vegetative to reproductive growth is a key developmental switch in flowering plants [26]. Environmental conditions such as temperature affect survival, growth, and fitness, particularly during key stages such as seedling growth and reproduction ([27], and literature cited therein). The timing of flowering in both wild and crop plants is a fundamental aspect of adaptation. The control of time to flowering has been studied in numerous species and is quite complex. Under normal circumstances, external cues such as low temperature (vernalization) and light (duration of exposure and intensity) are the prime factors that determine when plants will blossom [28]. The requirement for vernalization has been studied in many wild (and derived domesticated) species with both monocarpic habit (those that flower, set seed and die) and polycarpic species (perennials that can flower repeatedly over many years) showing a requirement for vernalization [29].

In several species, the response to vernalization varies with plant age. The requirement for vernalization usually increases or decreases linearly with respect to time. An increased requirement is found in species with a juvenile phase preceding the inductive phase. A decreased requirement is found in species with a quantitative response to vernalization, since, in these species, floral induction proceeds gradually with age even in the absence of a cold period [30]. In the present study, we examined the effect of low temperatures on the bolting and flowering time of germinating seeds and on different ages of the vegetative rosette of $L$. georgica plants. Experiments were performed during four successive growing seasons. From this, we hoped to gain innovative insights in the fields of phenological adaptation and germplasm exploitation of this WLR, aiming to improve our plant genetic resources (PGR) use efficiency for both basic research and potentially novel sources for breeding programs with domesticated lettuce.

\section{Materials and Methods}

\subsection{Plant Material}

A total of 121 wild L. georgica samples were used in this study (Table 1). The majority of original seed samples were collected from individual plants at 19 unique locations throughout six regions in Armenia (Figure 1(A) and Figure 1(B)). The remaining two original seed samples were collected as bulk samples 
Table 1. List of samples (total 121) representing 19 and two natural locations of wild Lactuca georgica in Armenia and Russian Federation, respectively, used for vernalization treatments. (a) Four samples used in experiments 2010, 2011, 2012, 2012-2013-i, and 2012-2013-iv; (b) 120 samples used in experiment 2012-2013-ii; (c) 21 samples used in experiment 2012-2013-iii.

(a)

\begin{tabular}{cccccccccc}
\hline $\begin{array}{c}\text { Pop. } \\
\text { no. }\end{array}$ & $\begin{array}{c}\text { Sample } \\
\text { no. }\end{array}$ & $\begin{array}{c}\text { Curator } \\
\text { Institute }\end{array}$ & $\begin{array}{c}\text { Collecting } \\
\text { date }\end{array}$ & Country & Locality & Region & Ln & Lt & El \\
\hline W6-37141 & 1 & USDA & $15 / 08 / 2009$ & Armenia & near Goris & Syunik & $46^{\circ} 19^{\prime} 36^{\prime \prime} \mathrm{E}$ & $39^{\circ} 30^{\prime} 13^{\prime \prime} \mathrm{N}$ & 1642 \\
W6-37155 & 1 & USDA & $17 / 08 / 2009$ & Armenia & Tashtun pass & Syunik & $46^{\circ} 10^{\prime} 25^{\prime \prime} \mathrm{E}$ & $39^{\circ} 05^{\prime} 28^{\prime \prime} \mathrm{N}$ & 2160 \\
W6-37160 & 10 & USDA & $18 / 08 / 2009$ & Armenia & near Shurnuh, Tass pass & Syunik & $46^{\circ} 23^{\prime} 30^{\prime \prime} \mathrm{E}$ & $39^{\circ} 23^{\prime} 39^{\prime \prime} \mathrm{N}$ & 1555 \\
W6-37168 & 3 & USDA & $20 / 08 / 2009$ & Armenia & $\begin{array}{c}\text { between Ughedzor } \\
\text { pass and Gndevaz }\end{array}$ & Vayots Dzor & $45^{\circ} 40^{\prime} 33^{\prime \prime} \mathrm{E}$ & $39^{\circ} 43^{\prime} 11^{\prime \prime} \mathrm{N}$ & 2058 \\
\hline
\end{tabular}

(b)

\begin{tabular}{|c|c|c|c|c|c|c|c|c|c|}
\hline $\begin{array}{l}\text { Pop. } \\
\text { no. }{ }^{*}\end{array}$ & $\begin{array}{l}\text { Sample } \\
\text { no. }^{*}\end{array}$ & $\begin{array}{l}\text { Curator } \\
\text { Institute }\end{array}$ & $\begin{array}{l}\text { Collecting } \\
\text { date }\end{array}$ & Country & Locality & Region & Ln & $\mathrm{Lt}$ & El \\
\hline W6-37138 & 1,2 & USDA & $15 / 08 / 2009$ & Armenia & $\begin{array}{l}\text { between Ughedzor } \\
\text { pass and Gorhayk }\end{array}$ & Syunik & $45^{\circ} 44^{\prime} 32^{\prime \prime} \mathrm{E}$ & $39^{\circ} 40^{\prime} 23^{\prime \prime} \mathrm{N}$ & 2174 \\
\hline W6-37140 & $1,2,3,4,5,6,7,8$ & USDA & $15 / 08 / 2009$ & Armenia & vicinity of Gorhayk & Syunik & $45^{\circ} 46^{\prime} 58^{\prime \prime} \mathrm{E}$ & $39^{\circ} 41^{\prime} 06^{\prime \prime N}$ & 2085 \\
\hline W6-37141 & $1,2,4,5,6$ & USDA & ** & & & & & & \\
\hline W6-37145 & $1,2,3,4,5,6$ & USDA & $16 / 08 / 2009$ & Armenia & near Srashen village & Syunik & $46^{\circ} 29^{\prime} 47^{\prime \prime} \mathrm{E}$ & $39^{\circ} 04^{\prime} 50^{\prime \prime} \mathrm{N}$ & 990 \\
\hline W6-37148 & $1,2,3,4,5,6$ & USDA & $17 / 08 / 2009$ & Armenia & $\begin{array}{l}\text { Pass between } \\
\text { Tsav and } \\
\text { Gyumarants }\end{array}$ & Syunik & $46^{\circ} 22^{\prime} 02^{\prime \prime} \mathrm{E}$ & $39^{\circ} 01^{\prime} 06^{\prime \prime N}$ & 2140 \\
\hline W6-37150 & 1,2 & USDA & $17 / 08 / 2009$ & Armenia & $\begin{array}{c}\text { near Gyumarants } \\
\text { village }\end{array}$ & Syunik & $46^{\circ} 22^{\prime} 01^{\prime \prime E}$ & $38^{\circ} 59^{\prime} 24^{\prime \prime} \mathrm{N}$ & 1420 \\
\hline W6-37154 & $1,2,3,4,5,6,7$ & USDA & $17 / 08 / 2009$ & Armenia & $\begin{array}{c}\text { between Lichk } \\
\text { village and } \\
\text { Tashtun pass }\end{array}$ & Syunik & $46^{\circ} 10^{\prime} 07^{\prime \prime} \mathrm{E}$ & $39^{\circ} 05^{\prime} 39^{\prime \prime} \mathrm{N}$ & 2040 \\
\hline W6-37155 & $1,2,3,4,5,6,7,8,9,10$ & USDA & ** & & & & & & \\
\hline W6-37159 & $1,2,3$ & USDA & $18 / 08 / 2009$ & Armenia & $\begin{array}{c}\text { crossroad to } \\
\text { Arachadzor village }\end{array}$ & Syunik & $46^{\circ} 26^{\prime} 30^{\prime \prime} \mathrm{E}$ & $39^{\circ} 20^{\prime} 21^{\prime \prime N}$ & 1320 \\
\hline W6-37160 & $1,2,3,4,5,6,7,8,9,10$ & USDA & ** & & & & & & \\
\hline W6-37167 & $1,2,3,4,5,6,7,8,9,10,11$ & USDA & $20 / 08 / 2009$ & Armenia & $\begin{array}{l}\text { vicinity of Sisian, } \\
\text { near Shaki waterfall }\end{array}$ & Syunik & $45^{\circ} 59^{\prime} 44^{\prime \prime} \mathrm{E}$ & $39^{\circ} 32^{\prime} 50^{\prime \prime} \mathrm{N}$ & 1621 \\
\hline W6-37168 & $1,2,3,4,5,6,7,8,9,10$ & USDA & ** & & & & & & \\
\hline 433 & $1,2,5,6,8$ & IoE & $30 / 08 / 2011$ & Armenia & Geghard I & Ararat & $44^{\circ} 48^{\prime} 51.2^{\prime \prime} \mathrm{E}$ & $40^{\circ} 08^{\prime} 13.7^{\prime \prime} \mathrm{N}$ & 1722 \\
\hline 434 & $1,2,3,4,5,6$ & $\mathrm{IoE}$ & $30 / 08 / 2011$ & Armenia & Geghard II & Ararat & $44^{\circ} 49^{\prime} 10.7^{\prime \prime E}$ & $40^{\circ} 08^{\prime} 25.7^{\prime \prime} \mathrm{N}$ & 1757 \\
\hline 441 & $1,3,4,5,6,7$ & IoE & $01 / 09 / 2011$ & Armenia & Tsovagiugh I & Gegharkunik & $44^{\circ} 58^{\prime} 15.7^{\prime \prime} \mathrm{E}$ & $40^{\circ} 37^{\prime} 31.1^{\prime \prime} \mathrm{N}$ & 1915 \\
\hline 442 & $2,3,4,5,7$ & IoE & $01 / 09 / 2011$ & Armenia & Tsovagiugh II & Gegharkunik & $44^{\circ} 58^{\prime} 58.5^{\prime \prime} \mathrm{E}$ & $40^{\circ} 37^{\prime} 55.1^{\prime \prime} \mathrm{N}$ & 1916 \\
\hline 443 & $2,3,4,5$ & IoE & $01 / 09 / 2011$ & Armenia & Tsovagiugh III & Gegharkunik & $45^{\circ} 00^{\prime} 22.0^{\prime \prime} \mathrm{E}$ & $40^{\circ} 37^{\prime} 37.5^{\prime \prime} \mathrm{N}$ & 1920 \\
\hline 444 & $1,2,3$ & IoE & $01 / 09 / 2011$ & Armenia & Tsovagiugh IV & Gegharkunik & $45^{\circ} 03^{\prime} 25.7^{\prime \prime} \mathrm{E}$ & $40^{\circ} 36^{\prime} 39.7^{\prime \prime} \mathrm{N}$ & 1915 \\
\hline 446 & $3,6,7,9,10,11,12,14,15$ & IoE & $04 / 09 / 2011$ & Armenia & Hamberd & Aragatsotn & $44^{\circ} 16^{\prime} 05.3^{\prime \prime E}$ & $40^{\circ} 22^{\prime} 28.7^{\prime \prime} \mathrm{N}$ & 1964 \\
\hline W6-40647 & $* * *$ & USDA & $25 / 07 / 2010$ & $\begin{array}{l}\text { Russian } \\
\text { Federation }\end{array}$ & Makhachkala & Dagestan & $47^{\circ} 25^{\prime} 26.8^{\prime \prime} \mathrm{E}$ & $42^{\circ} 52^{\prime} 40.1^{\prime \prime} \mathrm{N}$ & 480 \\
\hline W6-40651 & $* * *$ & USDA & $05 / 09 / 2010$ & $\begin{array}{l}\text { Russian } \\
\text { Federation }\end{array}$ & Achty & Dagestan & $47^{\circ} 38^{\prime} 47.7^{\prime \prime} \mathrm{E}$ & $41^{\circ} 23^{\prime} 59.3^{\prime \prime} \mathrm{N}$ & 1255 \\
\hline
\end{tabular}


(c)

\begin{tabular}{ccccccccc}
\hline $\begin{array}{c}\text { Pop. } \\
\text { no. }\end{array}$ & $\begin{array}{c}\text { Sample } \\
\text { no. }{ }^{*}\end{array}$ & $\begin{array}{c}\text { Curator } \\
\text { Institute }\end{array}$ & $\begin{array}{c}\text { Collecting } \\
\text { date }\end{array}$ & Country & Locality & Region & Ln & Lt \\
\hline 433 & $1,2,5,6,8,12$ & IoE & $* *$ & & & \\
434 & $1,2,3,4,5,6$ & IoE & $* *$ & & & \\
441 & $1,3,4,6,7$ & IoE & $* *$ & & \\
446 & $9,11,12,14$ & IoE & $* *$ & & \\
\hline
\end{tabular}

* Population (Pop.) and sample numbers; Curator Institute: USDA = USDA-ARS, National Plant Germplasm System, Plant Germplasm Introduction and Testing Research Unit, Pullman, WA, USA. IoE = Institute of Evolution, University of Haifa, Israel; $\mathrm{Ln}=$ longitude; $\mathrm{Lt}=$ latitude; $\mathrm{El}=$ elevation $(\mathrm{m}$ a. $\mathrm{s}$. 1.).

${ }^{* *}$ For details of this population, see above. ${ }^{* * *}$ Population was collected as a bulk seed sample.

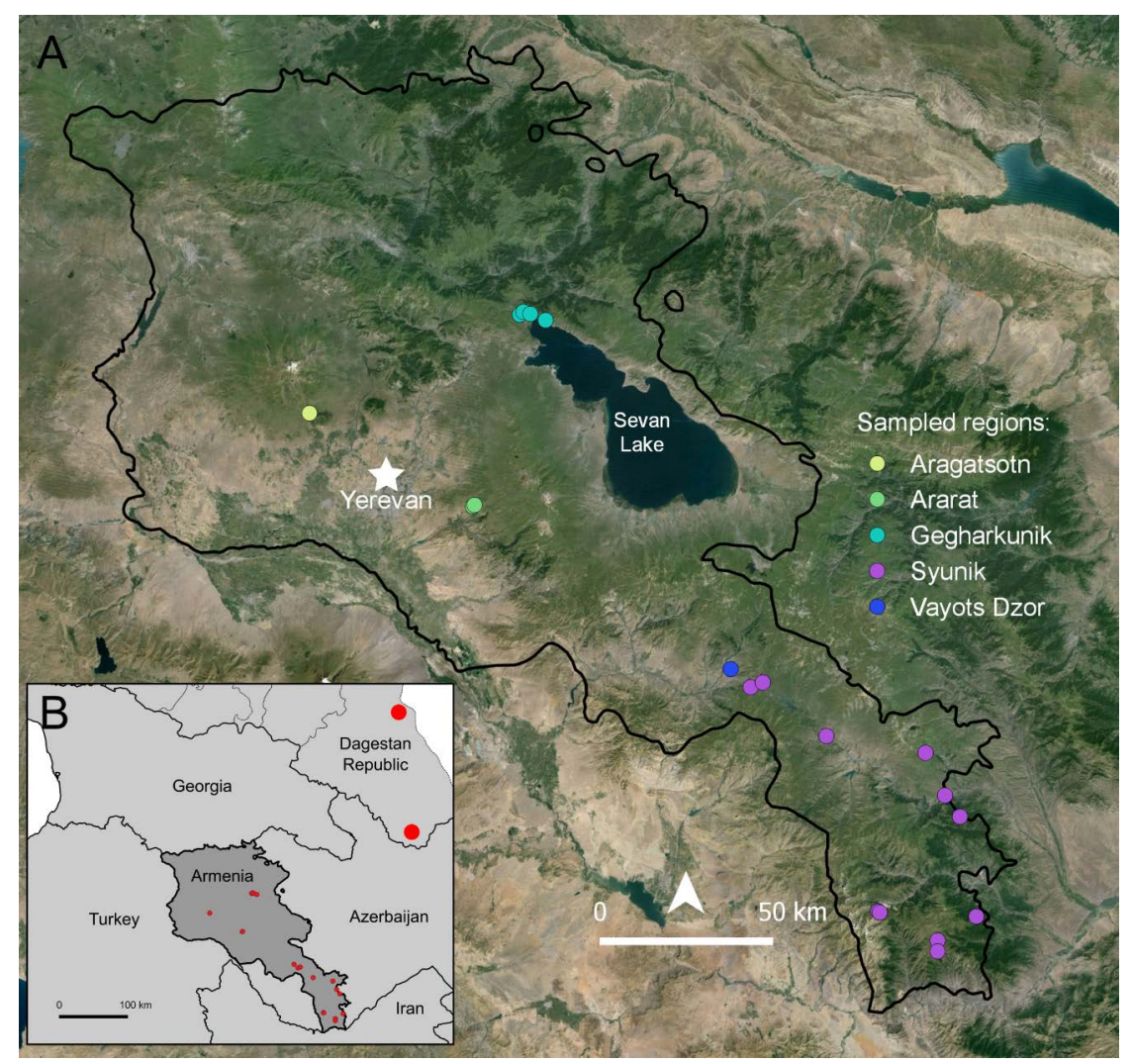

Figure 1. Map of 19 natural populations of wild L. georgica collected throughout five regions in Armenia ((A), (B)) and two populations collected in Dagestan Republic (B).

from whole populations at two individual locations in Dagestan, the Russian Federation (Figure 1(B)). Plant material was collected during expeditions conducted by: 1) Dr. George Fayvush (Institute of Botany, Armenian Academy of Sciences, Yerevan, Armenia) in 2009; 2) Dr S. Litvinskaya (Kuban State University, Krasnodar, Russian Federation) and Dr. R. Murtazaliev (Mountain Botanical Garden, RAS Dagestan Scientific Center, Makhachkala, Dagestan) in 2010; and 3) Dr. Alex Beharav (IOE, HU, Israel) in 2011. Data on the origin and location of collected samples are summarised in Table 1. Note that seeds from some natural populations of L. georgica were collected at lower altitudes than the previously reported [23] range of 1500 - 2300 m. In Armenia seeds were collected 
from populations starting from $990 \mathrm{~m}$, and in Dagestan a single population was found at $480 \mathrm{~m}$ (Table 1).

Various observations supported species identity of the $L$. georgica samples as following: 1) morphological and developmental evaluation, in their native habitats, according to botanical keys and some basic descriptors for wild Lactuca spp. [31] [32]; 2) during cultivation and re-determination for the current, as well as for our recent study (see details in Beharav et al., 2018 [9]), also according to morphological and developmental features; and 3) by Target Region Amplification Polymorphism (TRAP) markers, together with samples representing $L$ serriola, $L$. aculeata, $L$. saligna, $L$. virosa, and $L$. sativa [9]. A Neighbour-Joining tree clearly clustered the whole set of 238 samples according to their taxonomic determination. Samples from 2009 and 2010 collections were documented and deposited with the USDA-ARS National Plant Germplasm System, Western Regional Plant Introduction Station, Washington State University, Pullman, WA. Seed samples can be requested by US and worldwide researchers via the GRIN-Global database (https://npgsweb.ars-grin.gov/). Samples from 2011 collection were documented and deposited in the seed storage facilities of the IOE's Gene Bank. They are a part of a working collection, and may be shared subject to standard Material Transfer Agreements (MTA).

\subsection{Experiments and Growing Conditions}

Different vernalization treatments were evaluated at the Western Regional Plant Introduction Station, Pullman WA, USA, during four successive growing seasons, from 2010 until 2013, for a total of seven experiments. The majority of experiments $(2010,2011,2012,2012-2013-i$, and 2012-2013-iv) included plants from four seed samples from the 2009 collection: W6-37141-1, W6-37155-1, W6-37160-10, and W6-37168-3 (Table 1(a)). Experiments 2012-2013-ii included 120 samples from the 2009, 2010, and 2011 collections (Table 1(b)), while experiments 2012-2013-iii included 21 samples from the 2011 collection (Table 1(c)).

Vernalization treatments were applied to either germinating seed or older plants. The experiment in 2012 on older plants and 2012-2013-iv experiment used plants generated from the 2010 and 2011 experiments, respectively, on germinated seed. The plants used for these two experiments had previous exposure to vernalization as germinated seed. We assumed that these plants did not "remember" the old cold period, thus results can be attributed to the new treatments that included the various vernalization durations as described above. The plants used in the control treatment were the exception to this; they were generated from control treatments in the 2010 and 2011 experiments and had no exposure to vernalization. For the 2012-2013-ii and iii experiments, the plants used had no previous exposure to vernalization.

Treatments in each of the successive years were chosen based on previous results. In all experiments, vernalized plants were moved to growth chambers in order to precisely control the temperature and duration of the vernalization 
treatments. Germinating treated seeds were wet and placed at room temperature for between 2 to 10 days (imbibition period), then vernalization treatments were performed. Most experiments of this kind were planned so that all vernalization treatments ended on the same day, allowing the exposure of all plants to the same post-vernalization start date. When the control treatment (no vernalization) was applied, seeds were germinated at room temperature 5 - 7 days before the end of the cold period for the treated plants. After $48 \mathrm{~h}$ or when germinated, control seedlings were transplanted to soil. At the end of the vernalization period, depending on the temperature and duration of the cold treatment, seedlings either had not yet emerged or emerged and were at the cotyledonary stage. In other experiments, where vernalization treatments were applied to plants of different ages of the vegetative rosette, we used plants from the previous experiments or other control plants. These kinds of experiments were not optimal because the start and end vernalization date were staggered, however they did provide information if old plants with various ages can be stimulated to bolt.

\subsubsection{Experiment}

In a preliminary experiment in 2010, five different combinations of duration and vernalization temperature were applied to just germinating seeds $(48 \mathrm{~h}$ after imbibition), each included five plants (replicates) from four seed samples representing four populations from the 2009 collection (see Table 1(a)). Treatments were as follows: 1) 27 days at $4^{\circ} \mathrm{C}$;2) 27 days at $1^{\circ} \mathrm{C}$; 3) 37 days at $4^{\circ} \mathrm{C}$; 4 ) 37 days at $1^{\circ} \mathrm{C}$; 5) control. To sum up, a total of 25 plants from each sample and a total 100 plants were included in the experiment. All vernalization treatments ended on May 17, 2010. Plants were then moved to a lath house. The temperature from May 17 to May 30 ranged from $-0.9{ }^{\circ} \mathrm{C}$ to $24.7^{\circ} \mathrm{C}$, with an average temp. of $10.7^{\circ} \mathrm{C}$. The high temp. for June was $28.7^{\circ} \mathrm{C}$ on June 27. Day-length during this period was above $15 \mathrm{~h}$.

\subsubsection{Experiment}

Three vernalization durations were performed at $4^{\circ} \mathrm{C}$ using just germinating seeds $(48 \mathrm{~h}$ ) from the same four seed samples that were used in the 2010 experiment (see Table 1(a)): 1) 37 days with four replicates from each sample; 2) 44 days with four replicates; 3) control, i.e. without vernalization, with three replicates. A total of 11 plants from each sample, for a total of 44 plants were included in this experiment. All vernalization treatments ended on Aug. 7, 2011, then plants were moved for 14 days of post-vernalization adaptation in a growth room at $15^{\circ} \mathrm{C}$ under $18 \mathrm{~h}$-daylength. After 14 days, the temperature was raised to $18^{\circ} \mathrm{C}$ under $18 \mathrm{~h}$ daylength. The plants were under these conditions for the remainder of the experiment.

\subsubsection{Experiment}

A period of 120 days (4 months) of vernalization at $4^{\circ} \mathrm{C}$ was applied to a total of 12 plants, three plants (replicates) each from the same four seed samples that were used in the 2010 and 2011 experiments (see Table 1(a)), which had re- 
mained in the vegetative rosette stage for 656 days (21.6 months). Due to a limited number of plants, we had no controls (untreated). The plants in this experiment were started from seed placed in germination boxes on Apr. 07, 2010. Seedlings were transplanted to soil after germination and placed in the greenhouse $\left(20^{\circ} \mathrm{C}-25^{\circ} \mathrm{C}\right.$ under $12-18 \mathrm{~h}$-day length). On Jan. 23, 2012, plants were moved to a walk-in growth chamber set at $4^{\circ} \mathrm{C}$ under $12 \mathrm{~h}$-day length days until May 22, 2012, i.e. for 120 days, when they were moved outside to a lath house until producing seed. Temperatures in the lath house ranged from $1.7^{\circ} \mathrm{C}$ to $36.7^{\circ} \mathrm{C}$ with an average low of $8.6^{\circ} \mathrm{C}$ and an average high of $24.2^{\circ} \mathrm{C}$, with day length between 15.85 to $14.47 \mathrm{hrs}$.

\subsubsection{2-2013 Experiments}

We tested the effect of various vernalization durations at $4^{\circ} \mathrm{C}$ on various plant ages, as following:

1) We applied 73 (2.4 months) and 102 days (3.4 months) of vernalization, as well as no vernalization (controls), to just germinating seeds (eight - ten days after imbibition). Five, six, and eight plants (replicates) from each of the same four seed samples from the 2009 collection (see Table 1(a)) that were used in previous experiments were used for the 73 day, 102 day, and control treatments, respectively. A total of 76 plants, 19 plants from each seed sample, were included in this experiment. All vernalization treatments ended on Apr. 08, 2013. Plants were then placed in a growth room set at $18.3^{\circ} \mathrm{C}$ under $12 \mathrm{~h}$-day length until June 06, when they were moved outside to a lath house. Temperatures in the lath house ranged from $2.2^{\circ} \mathrm{C}$ to $36.1^{\circ} \mathrm{C}$ with an average temp of $18.9^{\circ} \mathrm{C}$ and day length ranged from $15.8 \mathrm{hrs}$ in June to $11.7 \mathrm{hrs}$ in September.

2) We also applied 168 days (5.5 months) of vernalization to plants $201-207$ days (6.6 - 6.8 months) old that included between one to 15 plants (replicates) each from a total 120 samples collected in 2009, 2010, and 2011 (see Table 1(b)). Seed were started July 25 to July 27, 2012 and transplanted to soil in 32 well planting trays from Aug. 03 to Aug. 09, 2012 and maintained in the greenhouse set at approximately $20^{\circ} \mathrm{C}$ with 12 to $18 \mathrm{~h}$ light. A total of 217 plants were included in this experiment. Vernalization started on Feb. 26, 2013, ended on Aug. 13. Plants were then placed in a growth room set at $18.3^{\circ} \mathrm{C}$ under $12 \mathrm{~h}$-day length until Sept. 03, 2013. They were then transplanted to 2 gal pots and moved outside to a lath house. Ambient temperatures ranged from $35^{\circ} \mathrm{C}$ to $-6.7^{\circ} \mathrm{C}$ with 10 - $13 \mathrm{~h}$ day length.

3) In parallel, we applied 55 - 113 days (1.8 - 3.7 months) of vernalization to 126 - 184 (4.1 - 6 month) old plants. Seeds were sown in germination boxes on July 25, 2012. Seedlings were transplanted to soil from Aug. 02 to Aug. 07 and placed in the greenhouse $\left(20^{\circ} \mathrm{C}-25^{\circ} \mathrm{C}\right.$ under $12-18 \mathrm{~h}$-day length). Plants were then separated into two sub-groups, as following: 1) all plants moved into $4^{\circ} \mathrm{C}$ on the same date (Nov. 28, 2012, i.e. 126 days old plants) and taken out after 58 (Jan. 25, 2013), 85 (Feb. 21, 2013), or 113 days (Mar. 21, 2013); 2) plants were placed in the cold treatment on staggered dates (Nov. 28, 2012; Dec. 27, 2012; 
and Jan. 25, 2013, i.e. 126, 155, and 184 days old plants, respectively), but all taken out on the same date (Mar. 21, 2013), i.e. 113-, 84-, or 55-days of vernalization, respectively. Generally, we used a single, sometimes two plants from each of 21 seed samples representing four populations from the 2011 collection (see Table $1(\mathrm{c})$ ). A total of four-five plants were used for each vernalization duration and each sub-group. In total, 14 plants were included in each of the two sub-groups. In addition, eight plants, two from each of the four populations were used as controls. For all treatments, there were a total of 36 plants included in this experiment. Plants from the $1^{\text {st }}$ sub-group ending vernalization treatment after 58 or 85 days were moved to the greenhouse with temperatures ranging, approximately, from $28.7^{\circ} \mathrm{C}$ to $17.5^{\circ} \mathrm{C}$ under 12 - $18 \mathrm{~h}$-day length until Mar. 05 when they were moved to a growth room set at $21.1^{\circ} \mathrm{C}$ under $18 \mathrm{~h}$-day length. Plants were moved because of the high greenhouse temperatures. On Mar. 21, 2013 all plants from both sub-groups were potted up from flats to 6-inch pots. On Mar. 28, all plants were moved to a walk-in growth chamber set at $18.3^{\circ} \mathrm{C}$ days $(18 \mathrm{hrs}), 12.8^{\circ} \mathrm{C}$ nights until June 04 , then they were potted to 2 gal pots and moved outside to a lath house. Ambient temperatures ranged from $36.1^{\circ} \mathrm{C}$ to $-3.9^{\circ} \mathrm{C}$ with 10.3 - $15.8 \mathrm{~h}$-day length.

4) Because our previous experiments were not conclusive we continued by applying 36-, 67-, 92-, and 129-days (1.2, 2.2, 3.0, and 4.2 months, respectively) of vernalization-as well as control (without vernalization)-under $12 \mathrm{~h}$-day length to plants with a long vegetative age (between approximately 15 - 20 months, depend on vernalization duration) of the vegetative rosette. We used the plants from the 2011 trial which ended their previous vernalization treatments (37 days, 44 days, or control) on Aug. 07, 2011, but did not respond with bolting. Due to limited number of plants, 67-, 92-, and 129-days vernalization durations included two plants (replicates) from each of the same four seed samples from 2009 collection (see Table 1(a)), that were used in previous experiments, while 36 days of vernalisation treatment and control included only a single plant from each sample. To sum up, a total of eight plants from each sample, (total of 32 plants) were included in this experiment. All vernalization treatments ended on Feb. 21, 2013. The plants were then placed in a growth room set at $21.1^{\circ} \mathrm{C}$ under $18 \mathrm{~h}$-day length until Mar. 28 , when they were moved outside to the lath house. Ambient temperatures ranged from a high of $30^{\circ} \mathrm{C}$ to a low of $-2.2^{\circ} \mathrm{C}$ from Mar. 28 to June 30 with an average of $11.8^{\circ} \mathrm{C}$. Day length ranged from 12.6 to $15.8 \mathrm{~h} /$ day.

\section{Results}

\subsection{Vernalization of Germinating Seeds}

\subsubsection{Experiment}

A total of 12 out of the 100 plants tested in the 2010 experiment bolted, all except one represented a single seed sample, W6-37160-10. Bolting dates (measured when flower stalk at $5 \mathrm{~cm}$ length) ranged from July 20 to Aug. 04, averaging 
71 days post-vernalization (dpv). First flower dates ranged from Aug. 11 to Sept. 14, averaged 98.3 dpv. First seed dates ranged from Aug. 25 to Sept. 29, averaged $112 \mathrm{dpv}$.

All control plants of W6-37160-10 remained strictly vegetative, but plants from all four treatments of this sample bolted, as follows: all five plants (replicates) treated for 37 days, $4^{\circ} \mathrm{C}$ bolted; three (out of five) treated for 37 days, $1^{\circ} \mathrm{C}$ bolted; two (out of five) treated for 27 days, $4^{\circ} \mathrm{C}$ bolted; and a single (out of five) treated for 27 days, $1^{\circ} \mathrm{C}$ bolted. Comparing vernalization duration (combined plants from the two treated temperatures), the percentage of bolted plants (eight out of ten $=80 \%$, Figure $2(\mathrm{~A})$ ) treated for 37 days was significantly higher (chi-square test: $\mathrm{df}=1 ; \chi^{2}=5.05 ; p=0.025$ ) compared to that (three out of ten $=$ $30 \%)$ of plants treated for 27 days. However, average bolting date $(70.3 \mathrm{dpv})$ of the three bolted plants treated for 27 days was very similar and not significantly different (un-paired t test: $\mathrm{df}=9 ; \mathrm{t}=0.15 ; p=0.885)$ from that $(70.9 \mathrm{dpv}$ ) of the eight bolted plants treated for 37 days.

Only a single plant (one of ten, Figure 2(A)) from W6-37141-1 treated for 37 days, $1^{\circ} \mathrm{C}$ bolted, while none of plants from either W6-37155-1 or W6-37168-3 bolted. Note that these two samples were originally collected at higher elevation as compared to the two samples with bolting plants (see Table 1(a)).

\subsubsection{Experiment}

Only one out of four plants (25\%, Figure 2(B)) from W6-37160-10 treated for 44 days at $4^{\circ} \mathrm{C}$ bolted. Date of bolting was Dec. 12, $127 \mathrm{dpv}$. All other treated (37 or 44 days at $4^{\circ} \mathrm{C}$ ) and control plants from all samples remained strictly vegetative.

\subsubsection{2-2013 Experiment (i)}

No plants treated as seedlings for 73 or 102 days of vernalization at $4^{\circ} \mathrm{C}$ or any of the control plants bolted.

\subsection{Vernalization of Plants with Rosette Leaves (Ordered by the Plant Age at the Time of Vernalization)}

\subsubsection{2-2013 Experiment (iii)}

Of the 4.1 - 6 months old plants only a single plant (one out of 8, Figure 2(D)), 446-12, from subgroup ii-treated for 55 days-bolted $104 \mathrm{dpv}$, flowered 143 $\mathrm{dpv}$, and set seed $200 \mathrm{dpv}$ (seed was produced on lateral or secondary stems as the central flower stalk on this plant died). No plants from any of the other two treatments $\left(84-85\right.$ or 113 days at $4^{\circ} \mathrm{C}$ ) or the control plants bolted.

\subsubsection{2-2013 Experiment (ii)}

Of the 6.6 - 6.8 months old plants, seven (Figure 2(E)) out of the total of 217 plants that were treated with 168 days of vernalization at $4^{\circ} \mathrm{C}$ bolted. These were W6-37167-3 (one of two), W6-40647 (one of 15), 441-5 (one of one), 443-3 (two of three), 444-3 (one of one), and 446-15 (one of one). We did not record bolting dates for this set of plants. 


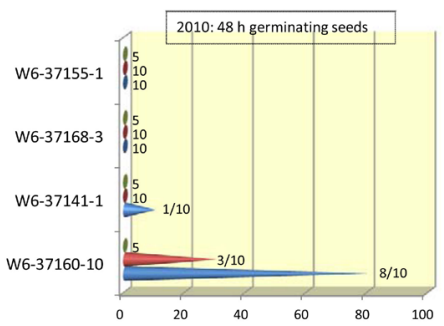

(A)

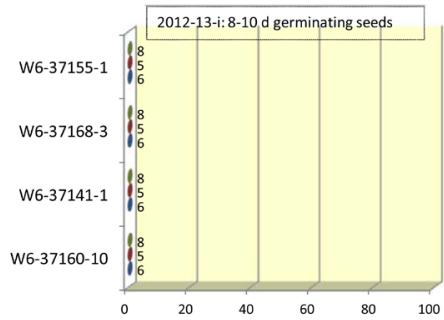

(C)

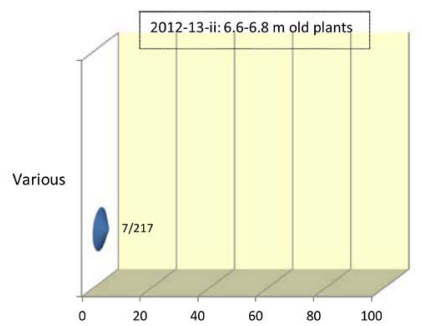

(E)

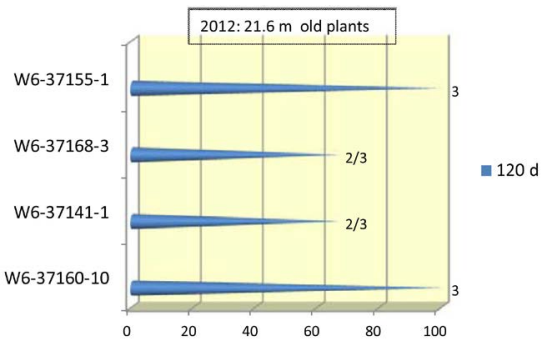

(G)

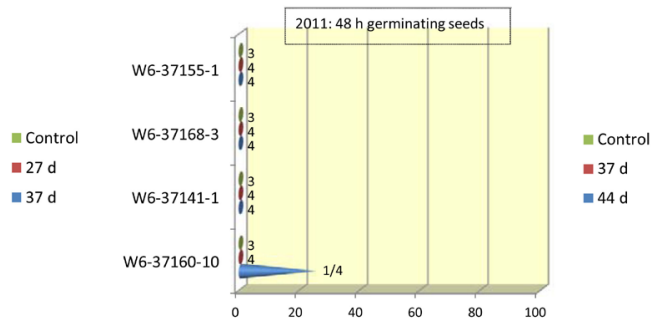

(B)

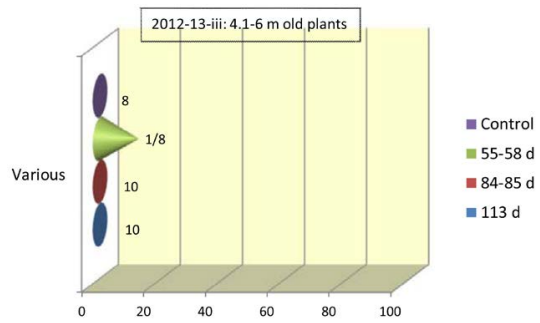

(D)

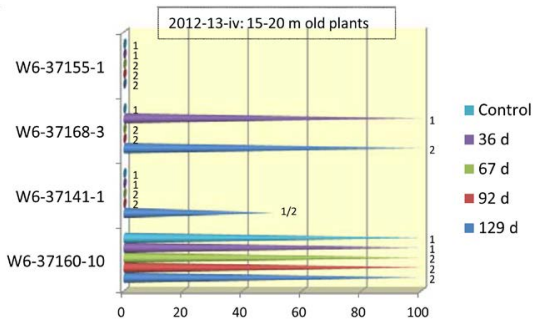

(F)

Figure 2. Bolting percentage of progenies of L. georgica sampled plants, originally collected throughout seven regions in Armenia and Dagestan Republic, after various vernalization treatments applied to just germinating seeds $((\mathrm{A})-(\mathrm{C}))$ or different ages of the vegetative rosette $((D)-(G))$. Bar number indicates the number of treated plants (where bolting percentage $=0$ or 100 ) or number of bolted out of the treated plants (where bolting percentage $>0$ and $<100$ ). Vernalization temperature was $4^{\circ} \mathrm{C}$ except for A where the results are pooled for the $1^{\circ} \mathrm{C}$ and $4^{\circ} \mathrm{C}$ treatments.

\subsubsection{2-2013 Experiment (iv)}

Of the 15 - 20 months old plants, a total of 13 out of the 32 plants included in the experiment, bolted. From these, all eight plants $(100 \%$, Figure $2(\mathrm{~F}))$ that represented sample W6-37160-10 bolted, regardless of vernalization duration (36-, 67-, 92-, and 129-days at $4^{\circ} \mathrm{C}$ ). The single control plant of W6-37160-10 also bolted on June 30, 2013, 129 days after the end of vernalization for the treated plants. From the seven W6-37160-10 treated plants, a single plant verna- 
lized for 67 days bolted $128 \mathrm{dpv}$, thus we assume that this bolting date was not dependent on vernalization, since it's very similar to the bolting date of the control plant. However, bolting dates for the remaining six W6-37160-10 vernalized plants (for various vernalization durations) ranged from Mar. 03 to Mar. 13, averaging $16.3 \mathrm{dpv}$. First flower dates of these six plants ranged from Apr. 04 to May 06, averaging $62.8 \mathrm{dpv}$, while first seed dates ranged from May 21 to May 31 , averaging $94.7 \mathrm{dpv}$. Of the 24 plants representing the other three samples, a single plant from W6-37141-1 (treated for 129 days) bolted $22 \mathrm{dpv}$, flowered 80 dpv, and seeded $103 \mathrm{dpv}$; all W6-37155-1 plants remained strictly vegetative; three plants representing W6-37168-3 bolted: two treated for 129 days (one bolted $20 \mathrm{dpv}$, while the second $100 \mathrm{dpv}$ ), and the single plant treated for 36 days (bolted $80 \mathrm{dpv}$ ).

\subsubsection{Experiment}

Of the 21.6 months old plants, a total ten out of the 12 plants bolted after the four months vernalization at $4^{\circ} \mathrm{C}$. All three plants $(100 \%$, Figure $2(\mathrm{G})$ ) from samples W6-37155-1 and W6-37160-10 bolted. Two of three plants from samples W6-37168-3 and W6-37141-1 bolted. Bolting dates ranged from June 09 to June 17 with an average of $21.1 \mathrm{dpv}$. First flower dates ranged from July 08 to Aug. 05, with an average of $60 \mathrm{dpv}$. First seed production ranged from July 23 to Aug. 9, averaged $74 \mathrm{dpv}$.

\section{Discussion}

This study is the first investigation of phenological adaptation of L. georgica natural populations and individuals from Armenia and Dagestan, specifically vis-a-vis vernalization requirements. It was shown that low temperatures play a major role in stimulating the reproductive process of $L$. georgica plants. Our results would suggest that: 1) L. georgica has an obligate (or nearly so) vernalization requirement since bolting occurred only in a single plant which was not exposed to low temperatures. The single control plant from sample W6-37160-10 that did bolt was a well developed plant, approximately 20 months of vegetative age (2012-2013-iv; Figure 2(F)). 2) Plant age, vernalization duration, and genotype of original sample have a role in bolting and flowering regulation of $L$. georgica plants. However, further experiments are required to define the minimal requirements for floral initiation of $L$. georgica. 3) Some samples of L. georgica appear to behave as non-obligate typical biennials. Bernier et al. [33] indicated that biennial plants with an obligate vernalization requirement normally undergo a juvenile phase during which they are insensitive to low temperatures. However, some of our tested germplasm, in which germinating $L$. georgica seeds did respond to the vernalization treatment, do not fit this scheme (Figure 2(A) and Figure 2(B)). It seems a vernalization treatment can serve as a substitute to the juvenile phase in some L. georgica genotypes. 4) A vernalization period of four months is adequate to stimulate bolting and flowering in plants with a well-developed vegetative rosette, from most-but not all $-L$. georgica samples, 
since most plants included in the 2012 (Figure 2(G)) and 2012-2013-iv (Figure $2(\mathrm{~F})$ ) experiments bolted after four months of vernalization. However, a longer vernalization duration is needed for some samples, even after attaining a well-developed vegetative stage. 5) To find the best solution for stimulating the reproduction process of $L$. georgica plants from populations that represent different climatic and edaphic environments, it seems that further study should focus on about $4-6$ months of vernalization at $4^{\circ} \mathrm{C}$ applied to plants with about 10 - 22 months of the vegetative rosette, with controlled post-vernalization conditions. Generally, high temperatures and short days may counteract the inductive action of cold temperatures on a plant's bolting and flowering [33]. 6) Due to their vernalization requirement, $L$. georgica germplasm may be used as a source for delayed bolting in breeding domesticated lettuce varieties. High temperature induces early bolting and flowering in lettuce [34]. So, increased temperatures from global climate change pose great challenges for lettuce production. Therefore, it is urgent to study the genetics and molecular mechanism of late bolting and flowering in lettuce by using WLRs to identify novel genes and alleles in known genes that were eliminated following lettuce domestication.

Along with the potential to use $L$. georgica as a source for delayed bolting, the biochemical features [19] [21], and downy mildew resistance [16] point to the uniqueness of this species. Even though recent results indicate that $L$. georgica probably belongs to the LGP-2 [9] [35], we suggest that it should be considered as an attractive germplasm resource for domestic lettuce breeding programs. Clearly, its uniqueness justifies identification and collection of additional samples from multiple locations throughout its geographic distribution.

Due to the limited extent of prior research on L. georgica, this study is by necessity exploratory, with the various experiments designed sequentially, and somewhat ad hoc, limited by the availability of seed samples from populations across the species' range, and by the huge amount of work to perform the type of experiments in the present study. It is hard to draw definitive statistically-supported conclusions about the contributions of plant age, vernalization time, and genotype to bolting probability and time to flowering from these results. Nevertheless, a pretty clear basic picture emerges, indicating that for most genotypes vernalization induces bolting with any consistency only in older plants, and there is evidence of genotypic variability in this behaviour. Clearly, more systematic follow-up research on L. georgica using germplasm from a wider geographic range is warranted.

\section{Acknowledgements}

AB wishes to thank Andreas Graner (Head, Genebank, Leibniz Institute of Plant Genetics and Crop Plant Research (IPK), Gatersleben, Germany) for the delivery of L. georgica seeds sample "LAC 327" in January, 2009. BH wishes to thank Alex Cornwall and Saber Glass (Washington State University, Pullman) for their technical assistance in the vernalization experiments. A special thank to Matěj Lövy (Faculty of Science, University of South Bohemia, České Budějovice, Czech 
Republic) for his production of Figure 1. This research was supported by USDA-ARS CRIS Project 2090-21000-032-00D and NIFA MultiState Project W006.

\section{Conflicts of Interest}

The authors declare no conflict of interest regarding the publication of this paper.

\section{References}

[1] Kilian, N., Gemeinholzer, B. and Lack, H.W. (2009) Tribe Cichorieae. In: Funk, V.A., Susanna, A., Stuessy, T. and Bayer, R., Eds., Systematics, Evolution, and Biogeography of Compositae, International Association for Plant Taxonomy, Vienna, 343-383.

[2] The Plant List (2013) Version 1.1. http://www.theplantlist.org

[3] Lebeda, A., Kř́stková, E., Kitner, M., Mieslerová, B., Jemelková, M. and Pink, D.A.C. (2014) Wild Lactuca Species, Their Genetic Diversity, Resistance to Diseases and Pests, and Exploitation in Lettuce Breeding. European Journal of Plant Pathology, 138, 597-640. https://doi.org/10.1007/s10658-013-0254-Z

[4] Zohary, D. (1991) The Wild Genetic Resources of Cultivated Letucce (Lactuca sativa L.). Euphytica, 53, 31-35. https://doi.org/10.1007/BF00032029

[5] Lebeda, A., Ryder, E.J., Grube, R., Doležalová, I. and Křístková, E. (2007) Lettuce (Asteraceae Lactuca spp.). In: Singh, R.J., Ed., Genetic Resources, Chromosome Engineering, and Crop Improvement, Vol. 3, Vegetable Crops, CRC Press, Taylor and Francis Group, Boca Raton, 377-472. https://doi.org/10.1201/9781420009569.ch9

[6] Beharav, A., Ben-David, R., Doležalová, I. and Lebeda, A. (2008) Eco-Geographical Distribution of Lactuca saligna Natural Populations in Israel. Israel Journal of Plant Science, 56, 195-120. https://doi.org/10.1560/IJPS.56.3.195

[7] Beharav, A., Ben-David, R., Doležalová, I. and Lebeda, A. (2010) Eco-Geographical Distribution of Lactuca aculeata Natural Populations in North-Eastern Israel. Generic Resources and Crop Evolution, 57, 679-686. https://doi.org/10.1007/s10722-009-9503-6

[8] Beharav, A., Khalifa, S. and Nevo, E. (2018) New Insights into the Range, Morphology, and Natural Hybridization of Wild Lactuca aculeata in Israel. Israel Journal of Plant Science, 65, 175-185. https://doi.org/10.1163/22238980-00001045

[9] Beharav, A., Hellier, B., Richardson, K.L., Lebeda, A. and Kisha, T. (2018) Genetic Relationships and Structured Diversity of Lactuca georgica Germplasm from Armenia and the Russian Federation among Other Members of Lactuca L., Subsection Lactuca L., Assessed by TRAP Markers. Genetic Resources and Crop Evolution, 65, 1963-1978. https://doi.org/10.1007/s10722-018-0669-7

[10] Jemelková, M., Kitner, M., Kř́stková, E., Beharav, A. and Lebeda, A. (2015) Biodiversity of Lactuca aculeata Germplasm Assessed by SSR and AFLP Markers, and Resistance Variation to Bremia lactucae. Biochemical Systematics and Ecology, 61, 344-356. https://doi.org/10.1016/j.bse.2015.07.003

[11] Kitner, M., Lebeda, A. Doležalová, I., Maras, M., Kř́ístková, E., Nevo, E., Pavlíček, T., Meglic, V. and Beharav, A. (2008) AFLP Analysis of Lactuca saligna Germplasm Collections from Four European and Three Middle East Countries. Israel Journal of Plant Science, 56, 185-193. https://doi.org/10.1560/IJPS.56.3.185 
[12] Kitner, M., Majesky, L., Křistková, E., Jemelková, M., Lebeda, A. and Beharav, A. (2015) Genetic Structure and Diversity in Natural Populations of Three Predominantly Self-Pollinating Wild Lactuca Species in Israel. Genetic Resources and Crop Evolution, 62, 991-1008. https://doi.org/10.1007/s10722-014-0203-5

[13] Lebeda, A., Kitner, M., Kř́stková, E., Doležalová, I. and Beharav, A. (2012) Genetic Polymorphism in Lactuca aculeata Populations and Occurrence of Natural Putative Hybrids between L. aculeata and L. serriola. Biochemical Systematics and Ecology, 42, 113-123. https://doi.org/10.1016/j.bse.2012.02.008

[14] Beharav, A., Lewinsohn, D., Lebeda, A. and Nevo, E. (2006) New Wild Lactuca Genetic Resources with Resistance against Bremia lactucae. Genetic Resources and Crop Evolution, 53, 467-474. https://doi.org/10.1007/s10722-004-1932-7

[15] Beharav, A., Ochoa, O. and Michelmore, R. (2014) Resistance in Natural Populations of Three Wild Lactuca Species from Israel to Highly Virulent Californian Isolates of Bremia lactucae. Genetic Resources and Crop Evolution, 61, 603-609. https://doi.org/10.1007/s10722-013-0062-5

[16] Beharav, A. Lactuca georgica, a New Wild Source of Resistance to Downy Mildew: Comparative Study to Other Wild Lettuce Relatives. European Journal of Plant Pathology. (Submitted for Publication)

[17] Petrželová, I., Lebeda, A. and Beharav, A. (2011) Resistance to Bremia lactucae in Natural Populations of Lactuca saligna from some Middle Eastern Countries and France. Annals of Applied Biology, 159, 442-455. https://doi.org/10.1111/j.1744-7348.2011.00507.x

[18] Beharav, A., Ben-David, R., Malarz, J., Stojakowska, A., Michalska, K., Doležalová, I., Lebeda, A. and Kisiel, W. (2010) Variation of Sesquiterpene Lactones in Lactuca aculeata Natural Populations from Israel, Jordan and Turkey. Biochemical Systematics and Ecology, 38, 602-611. https://doi.org/10.1016/j.bse.2010.07.007

[19] Beharav, A., Stojakowska, A., Ben-David, R., Malarz, J., Michalska, K. and Kisiel, W. (2015) Variation of Sesquiterpene Lactone Contents in Lactuca georgica Natural Populations from Armenia. Genetic Resources and Crop Evolution, 62, 431-441. https://doi.org/10.1007/s10722-014-0171-9

[20] Beharav, A., Malarz, J., Michalska, K., Ben-David, R. and Stojakowska, A. (2020) Variation of Sesquiterpene Lactone Contents in Lactuca altaica Natural Populations from Armenia. Biochemical Systematics and Ecology, 90, Article ID: 104030. https://doi.org/10.1016/j.bse.2020.104030

[21] Michalska, K., Beharav, A. and Kisiel, W. (2014) Sesquiterpene Lactones from Roots of Lactuca georgica. Phytochemistry Letters, 10, 10-12. https://doi.org/10.1016/j.phytol.2014.06.016

[22] Gabrielian, E. and Zohary, D. (2004) Wild Relatives of Food Crops Native to Armenia and Nakhichevan. Flora Mediterranea, 14, 5-80.

[23] Gabrielian, E. and Fragman-Sapir, O. (2008) Flowers of the Transcaucasus and Adjacent Areas: Including Armenia, Eastern Turkey, Southern Georgia, Azerbaijan and Northern Iran. A.R.G. Gantner Verlag, K.G.

[24] Lebeda, A, Doležalová, I., Feráková, V. and Astley, D. (2004) Geographical Distribution of Wild Lactuca Species (Asteraceae, Lactuceae). Botanical Review, 70, 328-356. https://doi.org/10.1663/0006-8101(2004)070[0328:GDOWLS]2.0.CO;2

[25] van Treuren, R., Coquin, P. and Lohwasser, U. (2012) Genetic Resources Collections of Leafy Vegetables (Lettuce, Spinach, Chicory, Artichoke, Asparagus, Lamb's Lettuce, Rhubarb and Rocket Salad): Composition and Gaps. Genetic Resources and Crop Evolution, 59, 981-997. https://doi.org/10.1007/s10722-011-9738-x 
[26] Blümel, M., Dally, N. and Jung, C. (2015) Flowering Time Regulation in Crops-What Did We Learn from Arabidopsis? Current Opinion in Biotechnology, 32, 121-129. https://doi.org/10.1016/j.copbio.2014.11.023

[27] Susila, H., Nasim, Z. and Ahn, J.H. (2018) Ambient Temperature-Responsive Mechanisms Coordinate Regulation of Flowering Time. International Journal of Molecular Sciences, 19, 3196. https://doi.org/10.3390/ijms19103196

[28] Srikanth, A. and Schmid, M. (2011) Regulation of Flowering Time: All Roads Lead to Rome. Cellular and Molecular Life Sciences, 68, 2013-2037. https://doi.org/10.1007/s00018-011-0673-y

[29] Amasino, M.A. (2005) Vernalization and Flowering Time. Current Opinion in Biotechnology, 16, 154-158. https://doi.org/10.1016/j.copbio.2005.02.004

[30] Purvis, O.N. (1961) The Physiological Analysis of Vernalization. In: Ruhland, W., Ed., Encyclopedia of Plant Physiology, Vol. 16, 76.

[31] Doležalová, I., Kř́stková, E., Lebeda, A. and Vinter, V. (2002) Description of Morphological Characters of Wild Lactuca L. spp. Genetic Resources (English-Czech Version). Horticultural Science (Prague), 29, 56-83. https://doi.org/10.17221/4461-HORTSCI

[32] Doležalová, I., Kř́stková, E., Lebeda, A., Vinter, V., Astley, D. and Boukema, I.W. (2003) Basic Morphological Descriptors for Genetic Resources of Wild Lactuca spp. Plant Genetic Resources Newsletter, 134, 1-9.

[33] Bernier, G., Kinet, J.M. and Sachs, R.M. (1981) The Physiology of Flowering. Vol. I. The Initiation of Flowers. CRC Press, Inc., Boca Raton.

[34] Hong, J.H., Kwon, Y.S., Choi, K.J., Mishra, R.K. and Kim, D.H. (2013) Identification of Lettuce Germplasms and Commercial Cultivars Using SSR Markers Developed from EST. Korean Journal of Horticultural Science and Technology, 31, 772-781. https://doi.org/10.7235/hort.2013.13055

[35] van Treuren, R., van Eekelen, H.D.L.M., Wehrens, R. and de Vos, R.C.H. (2018) Metabolite Variation in the Lettuce Gene Pool: Towards Healthier Crop Varieties and Food. Metabolomics, 14, 146. https://doi.org/10.1007/s11306-018-1443-8 